\title{
The Existence of President Instruction of the Republic of Indonesia Number 1 the Year 1991 on the Wide Spread of Compilation of Islamic Law in Indonesian Legal System
}

\author{
Fajar Sugianto \\ (Law Faculty of University 17 Agustus 1945 Surabaya, Jalan Semolowaru \\ No. 45, Surabaya-60118, Email: fajarsugianto@untag-sby.ac.id) \\ Slamet Suhartono \\ (Law Faculty of University 17 Agustus 1945 Surabaya, Jalan Semolowaru \\ No. 45, Surabaya-60118,, Email: suhartonoslamet61@gmail.com)
}

\begin{abstract}
:
President Instruction Number 1 Year 1991 is a legal instrument that became Indonesia's positive law regulating the Compilation of Islamic Law (KHI). However, the constitutional system and regulation system in Indonesia have undergone significant changes since the reform era. It raised another legal issue in the application and implementation of the Compilation of Islamic Law since it is not categorized as the source of law in Indonesia's legal system. It cannot be applied to the government directly because of lack of legal binding. Nevertheless, the existence of the President Instruction still provides recognition through join decision with the Ministry of Religion and the Supreme Court. Thus, the Compilation of Islamic Law can be institutionally applied in the Religious Court which positioned under the Indonesia's Supreme Court. Since then Judges easily apply the Compilation of Islamic Law as the legal source in resolving disputes in Muslim society.
\end{abstract}

\section{Keywords:}

President Instruction Number 1 Year 1991, Compilation of Islamic Law, Judges, the constitutional system and regulation system

\begin{abstract}
Abstrak:
Inpres 1/1991 merupakan instrumen hukum yang menjadikan hukum Islam sebagai hukum positif di Indonesia, akan tetapi perkembangan sistem ketatanegaraan dan sistem perundangundangan di Indonesia telah mengalami perubahan yang sangat pesat sejak era reformasi. Hal ini menimbulkan problem hukum baru dalam
\end{abstract}

al-1hkâm Vol.13 No.2 December 2018

DOI 10.19105/al-ihkam.v13i2.1727 
pemberlakuan Kompilasi Hukum Islam (KHI) mengingat kedudukan Inpres 1/1991 dalam sistem perundang-undangan tidak dikenal sebagai peraturan perundang-undangan. Dalam aspek kekuatan mengikat, Inpres tersebut tidak dapat diberlakukan untuk umum karena tidak mempunyai kekuatan mengikat umum dan hanya bersifat mengikat ke dalam terhadap pejabat yang berkedudukan lebih rendah pada 1 (satu) institusi. Kendatipun demikian eksistensi Inpres 1/1991 hingga hari ini masih diakui keberadaannya mengingat substansinya dibentuk melalui keputusan bersama antara Menteri Agama dengan Ketua Mahkamah Agung. Sehingga, Kompilasi Hukum Islam mengikat hakim-hakim peradilan agama yang berada di bawah lingkungan Mahkamah Agung. Para hakim dapat menggunakan Kompilasi Hukum Islam sebagai dasar hukum untuk menyelesaikan sengketa yang terjadi diantara masyarakat yang beragama Islam.

Kata Kunci:

Inpres 1/1991, Kompilasi Hukum Islam, Hakim, Sistem Ketatanegaraan dan Sistem Perundang-undangan

\section{Introduction}

According to its history, the dynamic of thought of Islamic Law in Indonesia has led towards transformative and remedial phenomena in introducing the growing, alive, advancing, and compatible dynamics. This is due to the fact that the thought of Islamic Law is in line with the natures of continuity and change which give emphasis on ability to adjust, having acceleration and persistence on its development, so that it has already set up unique characters inside. Effort of this movement has been pioneered far before the territory of Nusantara being split into many Countries. Indonesia as one of the active pioneers in this movement makes the thought of Islamic Law undergo a development in a doctrine of modern Islamic Law.

Pursuant to its existence, the Islamic Law experiences a very long route of history. Genealogically, it needs to see the background or the root of its history, namely during the entrance of Islam for the first time massively in Indonesia. There were various teachings on the entrance of Islam to Indonesia which are important to be exposed 
again in order to know the implication of Islamic exclusive characters at that time towards the development and growth of Islamic Law.

In connection with the aforesaid subject, Azyumadi Azra states that at least there are 3 (three) theories concerning with the entrance of Islam to Indonesia. First, Islam came to Indonesia in the 1st (first) century of Hijriyah or in the 7th (seventh) century AD from Hadramaut to the land of Aceh. Further, this theory has ever been strengthened in a Seminar on the Entrance of Islam to Indonesia in the year 1962 in Medan and supported by Naqub, Hamka, Hasjmi, Yunus, and several foreign historians such as Niemann, Holander, Crawfurd and Vetsh. However, the historians in Indonesia were also sufficiently open to give the remarks on the existence of intensive communication among Moslems originating from East India with the Indonesian community, so that it is quite reasonable to be considered or calculated in searching the entrance of Islam to Indonesia. ${ }^{1}$

There is also an opinion that this theory is based on and driven by the emotional wishes of the Islamic historians who want to confirm that the existence of Islam in Indonesia is as an authentic religion of the community, not as syncretism or even as peripheral, as accused by majority of Western writers. Abdul Rahman Haji Abdullah explained that during the 7th century AD, business activities had been established between the Arab merchants and the Indonesian communities. This reason is little bit different from the analysis of Western historians who also admitted this theory. Keyzer, for example, considered that the coming of Islam to Indonesia was originally from the Syafi'iyah Group (people following the Syafi'i School) with Egyptian nationality because it was the same with the madzhab/school developed by the Moslem in Indonesia from a different point of view.

Niemann and De Holander only mentioned Hadramaut (not Egypt), that also followed the Syafi'i School, as the source of the coming of Islam. These teachings at the beginning gave uncertainty in their answers if they were juxtaposed with the important problems concerning with the mechanism of religion conversion and Islamization. Certainly these merchants came merely for trading only,

1 Azyumadi Azra, "The Perspective of Islam in South East Asia" (Jakarta: YOI, 1989) viiviii. 
and it was impossible that their roles changed or became double, which at the same time also performed the religious preaching. By viewing the nature of this impossibility, it can be concluded that at that time the process of religion conversion and Islamization cannot be declared as having occurred. 2

The second theory stated that Islam came to Indonesia from Malabar and Gujarat, and neither from Arab nor Persia. This was as stated by Drewes which was then improved by Hurgronje in his book under a title "L'arabie et les Indies Neerlendaises", or "Revue de 1"Histoire des Religius".3 This theory confirmed that the Arabic people of Syafi'iyah School immigrated to India and then came to Indonesia by bringing the teachings followed ever since from Arab in which by those historians were called as Deccan Moslem. Therefore, these Deccan Moslems were really the first spreaders of Islam who came to this country, who were then followed by the sayyid and syarif who completed the process and mechanism of religion conversion by "baptizing" themselves to be the church leaders or king. This period was then specified as embryo of the birth of Islam in the 12th century $\mathrm{AD}$ in Indonesia.

In regards to this subject, Snouck Hurgronje himself based his view on various considerations, namely the lack of evidences stating that several Arab people came to Indonesia to spread Islam. Second, the existence of trading activities between the India merchants and the Indonesian communities had been established for a long time. There is strong evidence in the form of inscription kept in Sumatra region indicating the establishment of sufficiently strong relation between the merchants from Gujarat and the Communities in Sumatra. ${ }^{4}$

The third theory gave more emphasis on the early presence of Islam in Malay Peninsula (East Coastal direction, not from West Malacca) though Canton, Vietnam, Leran and Trengganu. From the view of its teaching, Islam in Phanrang (Vietnam) is the same with Islam in Peninsula, meanwhile an inscription found in Trengganu

2 Abdul Rahman Haji Abdullah, "The thought of Islamic People in Nusantara: History and Development till the 19th Century" (Kuala Lumpur, Dewan Bahasa dan Pustaka, 1990), 24.

3 Ahmad Manyur Suryanegara, "Finding the History: Discourse on Islamic Movement in Indonesia" (Bandung: Mizan, 1998), 75.

${ }^{4}$ Ibid., 77 
indicated the similarity with what found in Leran. Essentially as a theory, this teaching developed by Fatimi was criticized by Drewes who put the bases on the available evidences, particularly those related to this inscription constituting "a wild assumption". This is still added by the fact that the dominant legal mazhab (school) in Bengkali is Hanafi, not Syafi'i. 5

Based on the aforesaid subject, the existence of Islam in Indonesia is confirmed by the existence and development of Islamic law in Indonesian communities. Upon this foundation, the existence of Islamic law in Indonesia has the forms of normative law and formal law. ${ }^{6}$ As normative law, the Islamic law is accepted and consciously implemented by the Moslem, meanwhile as a tangible formal law, Islamic law has been legitimized as a positive law for Moslem. This materialization is carried out by using 2 (two) approaches, namely cultural approach and structural approach. ${ }^{7}$

The process of Islamic law legalization is carried out in formal means and by internalization into the national law without cornering formality of the Islamic law. ${ }^{8}$ Formal legalization for the Moslem is carried out by promulgating it to be the Government Regulation, Number 28 the Year 1977 on Endowments, Law No. 17 the Year 1999 on the Organizing on Hajj and Law No. 38 the Year 1999 on Tithe Management. Meanwhile, the internalization is materialized through the Law No.1 the Year 1974 on Marriage, Law No. 7 the year 1989 on Religious Court and Instruction of President No. 1 the Year 1991 on Spreading of Inpres 1/1991 (Compilation of Islamic Law ). ${ }^{9}$

\footnotetext{
5 Azyumadi Azra, "Ulama Network of Middle East and Nusantara Archipelago during the XVII \& XVIII Centuries" (Bandung: Mizan, 1994), 25-26.

${ }^{6}$ For Eelaboration on Legislation of Islamic Law into the National Law, read 5 Nispul Khoiri "Political Thought on Muhammadiyah Islamic Law", Al-Syir'ah, Journal of Science of Syari' ah and Law, Vol. 4u7, No. 1 (June, 2013), 215.

7 Compare with the contextual approach and the legal textual approach of Abdullah Saeed in Achmad Zaini, "Model of the Holy Qur'an Interpretation of Abdullah Saeed", Jurnal Islamica, Vol. 6, No. 1 (September 2011), 164.

8 Procedures in inserting the Islamic norms into the National Legal System by Jeje Abdul Rojak, "Inserting the Legal Politics into the Socialization of the Islamic Norms into the National Legal System", al Daulah, Vo. 7, No. 2 (October 207), 307.

9 For elaboration, see Zulfatun Ni'mah, "The Violation on Women's Rights in the Unilateral Divorce in Sasak Community from a Feminist Legal Theory", al-Ihkam, Vol. 13, No. 1 (June, 2018).
} 
Talking about the problem of Compilation of Islamic Law in Indonesia basically is talking about one of the aspects of the Islamic Law in Indonesia. If we talk about the Islamic Law in Indonesia, we will enter into a complex discussion, although the Islamic Law is in a very strategic position at the shop-window of community life dominated by the Moslem up to this present time. ${ }^{10}$ In more general view, the systemization of Compilation of Islamic Law is divided into 3 (three) types, namely the Islamic Marital Law becoming the part of the first book, the Inheritance Law stipulated in the second book and the Endowment Law put into the third book. Technically, each book consists of chapters which are then split into several articles and paragraphs.

In connection with the aforesaid subject, Hasballah Thaib states that from the historical point of view, the development of syari'at Islam (Islamic Law) in Indonesia undergoes the stagnant phase compared to that at the countries in Arabic Peninsula. ${ }^{11}$ This is caused by the belief or faith of majority of the Moslem to choose the taqlid method more than the ulama in settling the existing problems. Further, the social life and political condition at present always invite the polemic and disputes and are frequently banged into the State problems seemingly to be separated from the religious paradigm. The last, there is a skepticism upon the figh among the Moslem in Indonesia, since it is deemed as a result of thought of human mind which is impossible to have an absolute truth compared to the words or law directly revealed as God's revelation. ${ }^{12}$

Observing the above description, it is quite clear that Inpres 1/1991 states the Compilation of Islamic Law is a legal instrument that makes the Islamic Law as a positive law in Indonesia. However, the development of constitutional system and legislation system in Indonesia had undergone a very fast change since the reform era. This creates new legal problems in implementation of the Islamic Law Compilation, due to the fact that its position at the legislation system

10 Abdurrahman, "Compilation of Islamic Law in Indonesia", the $3^{\text {rd }}$ (Third) Edition (Jakarta: Akademika Pressindo, 2001), 1-2.

11 Hasballah Thaid, "Tajdid Re-actualization and Elasticity of the Islamic Law". The paper is presented at the Seminar of the Judges and Court Secretaries of the Religious Courts throughout the North Sumatra Region (Medan: June 12, 2002), 12.

12 Ibid., 13 
has already undergone a change. Pivoting on this matter, academically a question can be raised as follows, "How is the Existence of Compilation of the Islamic Law in Indonesian Legal system?"

\section{Research Methodology}

This writing is a legal research, namely a process to find the legal regulation, legal principles, or legal doctrines in order to answer the legal issues encountered. ${ }^{13}$ In answering the legal issues raised in this writing, 2 (two) approaches are used, namely Statute Approach and Conceptual Approach.

The Statute Approach applies the legislation regulations related to the existence of Compilation of the Islamic Law in Indonesian legal system, comprising of the State Constitution of the Republic of Indonesia the Year 1945, the Law No. 12 the year 2011 on Establishment of Legislation Regulation and President Instruction Number 1 the year 1991 on the Spread of Compilation of the Islamic Law. In addition, in this writing, the Conceptual Approach is also used to elaborate the legal concepts related to the existence of Compilation of the Islamic Law in Indonesian legal system in order to solve or to answer the existing legal issues or legal problems. ${ }^{14}$

\section{Discussion}

Compilation of Islamic Law is set up through a Joint Decree between Chief Justice of Supreme Court and Minister of Religious Affairs then supported well and warmly welcomed by ulama and the religious leaders. Therefore, the Compilation of Islamic Law is actually dug up from the root of thought of the ulama which is then discussed to find the understanding in order to be jointly agreed to produce an ijma' which is then used as the source of establishment of law and legislation by the State. ${ }^{15}$

Consensus or ijmấ of the aforesaid ulama at the national legislation system can be categorized as unwritten law whose existence is acknowledged, but its implementation is not put under a

\footnotetext{
13 Peter Mahmud Marzuki, "Legal Research" (Jakata: Prenada Media, 2005), 35.

14 Ibid., 93.

15 Cik Hasan Basri, "Compilation of Islamic Law in National Legal System" (Jakarta: Logos Wacana Ilmu, 1999), 8.
} 
force. Therefore, a positivation needs to be carried out into legislation formally applicable in Indonesia. Compilation of the Islamic Law in Indonesia is prepared in 2 (two) phases, namely 'Inventory Phase' of the main materials becoming the load or content in Compilation of the Islamic Law, and 'Establishment Phase' of Compilation of the Islamic Law by pouring the materials dug up from the source of Islamic Law into the legislation regulations formally applicable in Indonesia.

The birth of Compilation of Islamic Law historically confirms that the Islamic Law is a law that has already been in existence for a long time and stays in life aspects of Moslem communities in Indonesia. The second, the demand of followers/holders of Islam religion in Indonesia wishing to have the law adopted from the Islamic Law under the basis of religious faith in order to have a legal certainty in holding the activities with the Islamic nuance. Third, a strong wish of the ulamas to establish a written law pursuant to legislation standard, so that the existence of Islamic Law has the legality and legitimization from the State and the existence of Compilation of Islamic Law constitutes a transformation of unwritten law into the positive law in Indonesia. ${ }^{16}$

In connection with the position of Islamic Law Compilation in legal system in Indonesia can at least be explained through 4 (four) things, namely: 1) Position of Compilation of the Islamic Law is constitutionally admitted and even it is also admitted by Pancasila the State Ideology, as stated on its consideration at Inpres 1/1991. 2) Legalization of Compilation of the Islamic Law is carried out through a legal instrument in the form of President Instruction, which is then followed up by a Decree of Minister of Religious Affairs. 3) It is dug up from the source of Islamic Law already been studied and agreed by the ulamas pursuant to the condition of Moslem community in Indonesia. 4) Legality and legitimization of Islamic Law Compilation are acknowledged by the Judges of the Religious Court, so that it can be used as a basis and reference and used as a guideline in adjudicating certain disputes occurring among the Moslem. ${ }^{17}$

\footnotetext{
16 Abdul Gani Abdullah, "Introduction to Compilation of the Islamic Law in Indonesian Legal Structure", 1st Edition (Jakarta: Gema Insani Press, 1994), 63.

17 Abdurahman, Op. Cit., 9-10.
} 
Further, Compilation of the Islamic Law as the primary reference in settling every dispute occurring among the Moslem based on several factors, namely:1) Position of Compilation of the Islamic Law as a legal product formally specified by the State. 2) The substance of Compilation of the Islamic Law is formulated at the ijma' of the ulamas who have already become the role model of the Moslem. 3) The culture of Moslem community based on the religious faith, and 4) The 'easiness' of the Moslem community in Indonesia in settling the legal and social problems by relying on Compilation of the Islamic Law. ${ }^{18}$

Apart from the aforesaid factors, the other factor becoming a strong basis in the acceptance of Compilation of the Islamic Law in community is due to the fact that the formulation process of Islamic Law Compilation is conducted by involving many parties and several stakeholders. Moreover, several parties involved consist of the elites considered as having sufficient scientific capacities, so that the truth of every argumentation formulated becomes so accurate.

However, just like the process of nusantara Islamization, the existence of Compilation of the Islamic Law in Indonesia frequently experiences obstacles and difficulties. This is due to the fact that Compilation of the Indonesian Law is still at the new age and not so well-known by the Moslem society widely. Therefore, the factor of socialization becomes one of the major problems how come Compilation of the Islamic Law has not yet fully become the guideline for the whole Moslem society. The second, the problems arising at the Moslem community in Indonesia are the difference in mazhab and school among the religious leaders, the role models of community, moreover the religious leaders who are not involved in formulation process for Compilation of the Islamic Law, so that this matter also gives influence to their followers to put aside the existence of Compilation of the Islamic Law in considering the legal affairs. Third, a fundamental conflict frequently occurs among the norms stipulated at Islamic Law compilation and culture of the local community and their customary law, particularly when it concerns with the

18 Ibid., 15. 
Inheritance Law certainly varies based on the place, tribes, ethnics, and the like. ${ }^{19}$

Further, in connection with Compilation of the Islamic Law functionally, in a very simple thought, Hasan Basri refers it as a law establishment process originated from codification. He states that Compilation of the Islamic Law is the origin of law codification established by the State through the law instruments which later on become the masterpiece deriving from donation of thought from the Moslem Experts to fulfill the demand and expectation of the Indonesian Moslem communities. ${ }^{20}$

Having a difference of opinion, Bustanul Arifin confirms that Compilation of Islamic Law constitutes the compilation of opinions of Moslem Intellectuals on figh concerning with the daily problems of the Indonesian Moslem community. Therefore, the presence of Compilation of the Islamic Law is not a codification which later on will change it with something completely new. ${ }^{21}$

The legal basis underlying the application of the Islamic Law Compilation is the Inpress 1/1991 which directly gives the instruction to Minister of Religious Affairs to socialize it to the whole communities and the government institution. Thus, pursuant to its function, the aforesaid Instruction of President is just merely limited to the instruction to socialize the Compilation of Islamic Law.

Further, Inpres 1/1991 is followed up by a Decree of Minister of Religious Affairs, No. 154/1991 (Kepmenag 154//1991) as a response to the Inpres 1/1991 in which on its considerations they describe the subjects as follows:

a. Instruction of President of The Republic of Indonesia Number 1 the Year 1991, dated June 10, 1991, instructing the Minister of Religious Affairs to widely spread the Compilation of Islamic Law in order to be used by the Government Agencies and communities who need them.

19 Cik Hasan Basri, Op.Cit.

20 Ibid., 15.

21 Bustanul Arifin, "Compilation: The Figh in Law Language", Jurnal Pesantren, Volume II, No. 2 (September, 1985), 28. 
b. That the aforesaid wide spread of Compilation of the Islamic Law needs to be carried out as best possible and in full responsibility.

c. Therefore, a Decree of Minister of Religious Affairs of The Republic of Indonesia needs to be issued on the implementation of the said Instruction of President of The Republic of Indonesia Number 1 the Year 1991, dated June 10, 1991.

Viewing the aforesaid subjects, there are at least 3 (three) things need to be underlined in Inpres 1/1991 and Kepmenag 154//1991, namely:

1) Instruction to socialize the Compilation of Islamic Law for the community in need becomes the official reference in settling the disputes occurring among Moslem in Indonesia.

2) Compilation of the Islamic Law becomes a confirmation on the enactment of law related to the Islamic Law, such as the Marital Law and the like.

3) Confirming the scope of its enactment, namely at the government agencies related to the religious affairs, such as the Religious Court and for the Moslem community who needs it for official reference having the source of the Islamic Law. ${ }^{22}$

Based on those 3 (three) subjects stated above, it is quite clear that the State admits the existence of Islamic Law deemed sacred for majority of the Islamic people. Therefore, the State accommodates the said need, so that it has already fulfilled the element of sociological validity in the establishment of the Islamic Law Compilation in Indonesia.

Further, in connection with the primary source in formulation of the Compilation of Islamic Law, there are at least 6 (six) sources, namely:

1) Legal products of the legislative and executive institutions, such as the Law No. 22/1946, Law No. 32/1954, Law No. 1/1974, Law No. 7/1998, Government Regulation No. 9/1975, Government Regulation No. 28/1977.

\footnotetext{
22 Zainuddin Ali, "Islamic Law: Introduction to Islamic Law in Indonesia" (Jakarta: Sinar Grafika, 2006), 61-62.
} 
2) Judgments of the Judges of Religious Court related to the matters of Inheritance and Settlement of Conflicts related to Customary Law of Inheritance. ${ }^{23}$

3) Academic study from the Islamic universities, such as Institute of Islam Religion through the Workshop, Seminars and the like.

4) Legal opinions of various experts inventoried from various regions, such as Surabaya, Mataram, Ujung Pandang, Bandung and Palembang.

5) Minutes on the results of comparative studies in the countries having the Islamic bases, such as The Republic of Morocco, Egypt and Turkey, and

6) Outputs of discussion of the ulamas throughout Indonesia who gathered in Jakarta from February 2 - 6, 1989. ${ }^{24}$

The aforesaid 6 (six) sources are called as "Law in Abstracto" 25 by Andi Syamsu Alam, because it is deemed it had solved a lot of problems of the Moslem when they have disputes with other Moslem, although the source in the form of judgments of the Judges theoretically are called as "Law in Concretto".

In historical documents, far before the presence Inpres 1/1991, there were several parties who had studied the constitutional law in depth who requested the positivation of the Islamic Law to be carried out by the government regulation, President regulation, and even Law. Because, the aforesaid legal instrument constitutes the type of suitable regulation to be used in establishing the positive law extracted from the Islamic Law. ${ }^{26}$

Concerning with the nature of Inpres 1/1991 in perspectives of constitutional law and in administration law, it is stated that the Instruction of President is a legal instrument having the concrete and

${ }^{23}$ Sofyan A.P., Kau \& Zulkarnain Suleman, "Existence of Customary Law in Compilation of the Indonesian Islamic Law", Al-Adalah, Volume XIII, No. 2 (December, 2016), 169.

24 Ibid., 66.

${ }^{25}$ Andi Syamsu Alam, "Existence of Draft of Law on Applied Law on Religious Court in the Field of Marriage for the Religious Court". This paper is presented on Seminar on Draft of Law on Applied Law on Religious Court in the Field of Marriage (Padang: dated June 11, 2005), 1.

26 Dadang, Muttaqien, "Religious Court and Compilation of Islamic Law in Indonesian Legal Structure" (Yogyakarta: UII Press, 1999), 45 
individual natures and occurs in hierarchical relation in an institution. It means that the binding power contained at the Instruction of President is only applicable to individuals in lower rank in an institution. It is quite different from the binding power of the legislation regulation, such as the President Regulation, Government Regulation and the Law applicable and have general binding power (erga omnes). ${ }^{27}$ Based on this matter, the intended address of Inpres 1/1991 is the Minister of Religious Affairs individually, so that it is followed up through the Decree of Minister of the Religious Affairs (Kepmenag 154/1991).28

Observing this subject, the Compilation of Islamic Law has the positions as follows:

1) The product of Islamic Law positivation in Indonesia which is not the type of legislation regulation as confirmed at the Paragraph (1) of Article-7 of Law No. 12/2011.

2) Compilation of Islamic Law is made to be the voluntary reference at the Religious Court Institution and becomes the permanent legal ground basing the judgments of the Judges of the Religious Court.

3) Inpres 1/1991 has no general binding power just like the legislation regulations. Thus, each person, particularly the Judge is not obliged to take the Compilation of Islamic Law as a guideline, although it is not forbidden either to refer to Compilation of the Islamic Law.

4) Inpres 1/1991 is only addressed to Minister of Religious Affairs as the assistant of President in holding the state administration. Therefore, the intended address of the Inpres 1/1991 is special for the Minister of Religious Affairs. ${ }^{29}$

Further, paying close attention to the process of positivation of the Islamic Law in Indonesia, Nasrun Harun, as quoted by Habiburrahman states that the efforts or the wishes to make the change or even to replace the Compilation of Islamic Law is very

27 Abdul Latif and Hasbi ali, "Politics of Law", 2nd Edision. (Jakarta: Sinar Grafika, 2011), 68 .

28 Ibid., 48.

29 Bagir Manan, "Theory and Constitutional Politics" (Yogyakarta: Law Faculty Indonesia Islamic University, 2003), 211. 
strong if it is seen from the output of aspiration screening from the Moslem community in Indonesia. ${ }^{30}$ This is due to the fact that the form of legal product of Compilation of the Islamic Law is the President Instruction academically and practically is not the legislation regulation, so that it does not have the same power as that of the legislation regulation. This matter certainly will raise a new legal uncertainty in implementing the Islamic Law in Indonesia.

Precisely, such a condition will raise a perception that the effort of positivation of the Islamic Law is carried out not so seriously, because it has dwarfed the meaning of positivation by establishing the legal product without having the forcing power just like the legislation regulation. On the other hand, the wish to change or to replace the Compilation of Islamic Law derives from the non-Syafi'i group who considers that Compilation of Islamic Law is having too much Syafi'iyah pattern. In reality, the mazhab of Islamic thought in the field of figh in Indonesia is not only Syafi'i, but there are also having the mazhab of Maliki, Hambali, Hanafi and even Syi'ah. Some of those schools are not only followed by the Islamic community and thinkers, but also some parts of Judges of the Religious Court, who are also the followers of those madzhabs. ${ }^{31}$

Considering the description as explained above, the writers are in the opinion that the Moslem in Indonesia have the right guaranteed by the constitution to struggle for the establishment of the Islamic Law in Indonesia by means of conducting the positivation of Islamic Law in codified ways at the level of law through the line of power, such as becoming the legislative members who later will be given the authority to establish the law together with the Government. In addition, the effort to have the positivation of the Islamic Law can be carried out at the educational institutions and preaching and conveying the aspiration through the rooms of public c discussions or can also be conducted through the testing to the legislation

\footnotetext{
30 Maimun and Ainul Haq, "Tracing down motivation and Effectiveness of Regional Regulation Having the Syariah Nuance in Pamekasan", Al-Ihkam, Volume 13, No. 1 (June, 2018), 132.

31 Habiburrahman, "The Marriage of a Moslem Woman with a Foreign Citizen". This paper is presented at the Seminar on Draft of Law on the Applied Law of Religious Court in the Field of Marriage, held at IAIN Imam Bonjol (Padang, dated June 11, 2006), 6-7.
} 
regulations deemed in controversy with the religious values, especially Islam, as guaranteed in Article-29 of the Constitution of The Republic of Indonesia the year 1945.

To overcome new polemics on the existence of Inpress 1/1991, the writers are in the opinion that it is better if President together with the House of Representatives of The Republic of Indonesia start to formulate the law or something of the same level with it whose content material stipulates about the Islamic Law as a whole, either the ones related to the family law or the law of syari'ah economy. It means that the establisher of law performs codification to the Islamic Law becoming parts of the legal system applicable in Indonesia, apart from the customary law, western law and other formal sources of law.

This is important, considering the fact that the existence of Inpres 1/1991 is just limited to the instruction in official work relation between superior and the subordinate which can occur only once and finished and not applicable continuously just like legislation regulation, as long as it is not revoked or annulled by judicial institution shall remain applicable in an unlimited time. Such a thought is based on the legal problem solving in order to give the way out for the legal problems available in the enactment of Compilation of Islamic Law in Indonesia, so that it can provide the legal certainty for the whole parties, either the Judges or the communities and certainly the most important thing is that it can give the justice to the Moslem citizen in settling certain disputes seemingly more compatible than the Western Law.

\section{Conclusion}

Based on the above explanation, it is concluded that Inpres $1 / 1991$ is a legal product with individual and concrete natures and is applicable in an institution vertically between superior and subordinate. Such legal product is not known as a legislation regulation, either conceptually or normatively as confirmed in Paragraph (1) of Article-7 of Law Number 12 the Year 2011 on Establishment of Legislation Regulation.

From the view point of binding power, Inpres 1/1991 only binds the officials having a lower position in 1 (one) institution. Thus, the said Instruction of President cannot be applied generally, because it does not have any binding power. However, the existence of Inpres 
1/1991 up to this present time is still acknowledged due to the fact that the substance of the Islamic Law Compilation becoming the content and Instruction of President was established through a Joint Decree between Minister of Religious Affairs and Chief Justice of the Supreme Court. Thus, Compilation of the Islamic Law binds the Judges of the Religious Court who are structurally under or at the environment of the Supreme Court. In this way, those Judges can use the Compilation of Islamic Law as the legal basis to settle the disputes arising among the Moslem community.

Based on the aforesaid subjects, although Inpres 1/1991 is not included in the category of legislation regulation and has no general binding power just like the law, but its existence and its enactment are based on the forcing power established from the faith in holding the Islam Religion. In the future, however, the writers suggest that the Compilation of Islamic Law is established to be the law codified with the whole provisions abstracted from the principles or the values of Islamic Sharia so that it will have much stronger position in Indonesian legal system.

\section{Bibliography}

A.P. Sofyan, Kau \& Zulkarnain Suleman, "Eksistensi Hukum Adat dalam Kompilasi Hukum Islam Indonesia" (Existence of Customary Law in Compilation of the Indonesian Islamic Law"), Al- Adalah, Volume VIII, No. 2 (December, 2016).

Abdullah, Abdul Gani, "Pengantar Hukum Islam dalam Tata Hukum Indonesia" (Introduction to Islamic Law in Indonesian Law Structure), Jakarta: Gema Insani Press, 1994.

Abdullah, Abdul Rahman Haji, "Pemikiran Umat Islam di Nusantara: Sejarah dan Perkembangan Hingga Abad ke-19". (The thought of Moslem in Nusantara: History and Development until the 19th Century), Kuala Lumpur: Language Council and Library, 1990.

Abdurrahman, "Kompilasi Hukum Islam Indonesia" (Compilation of the Indonesian Islamic Law) 3rd Edition, Jakarta: Akademika Pressindo, 2001. 
Alam, Andi Syamsu, "Eksistensi Rancangan Undang-Undang tentang Hukum Terapan Peradilan Agama Bidang Perkawinan bagi Peradilan Agama" (Existence of Draft of Law on the Applied Law of Religious Court in the field of Marriage for the Religious Court). This paper is presented at the Seminar on Draft of Law on the Applied Law of Religious Court in the Field of Marriage, held in IAIN Imam Bonjol, Padang, on June 11, 2005.

Ali, Zainuddin, "Hukum Islam: Pengantar Hukum Islam di Indonesis" (Islamic Law: Introduction to the Islamic Law in Indonesia), Jakarta: Sinar Grafika, 2006.

Arifin, Bustanul, "Kompilasi: Figh Dalam Bahasa Undang-Undang" (Compilation: Figh in Language of Law), Jurnal Pesantren, Volume II, 1985.

Azra, Azyumadi, "Jaringan Ulama Timur Tengah dan Kepulauan Nusantara Abad XVII \& XVIII" (Network of Ulamas of Middle East and Nusantara Archipelago during the 17th and 18th Centuries), Bandung: Mizan, 1994.

. "Perspektif Islam Asia Tenggara" (Perspectives of Islam in South East Asia), Jakarta: YOO, 1989.

Baehaqi, Ja'far, "Pengaruh Islam dan Budaya dalam Pembentukan Hukum di Indonesia" (Influences of Islam and Culture in Law Establishment in Indonesia), al-Ihkam, Volume II, No. 2, December, 2016.

Basri, Cik Hasan, "Kompilasi Hukum Islam Dalam Sistem Hukum Nasional" (Compilation of Islamic Law in National Legal System), 1st Edition, Jakarta: Logos Wacana Ilmu, 1999.

Faidi, Ahmad, "Sistem Kekhalifahan dan Konstruksi Budaya Politik Arab "(Caliphate System and Cultural Construction in Arab Politics), alIhkam, Volume 13, No. 1 (June, 2018).

Habiburrahman, "Perkawinan Perempuan Muslimah Dengan Warga Negara Asing" (Marriage between a Moslem Woman and a Foreign Citizen). This paper is presented at the Seminar on Draft of Law on the Applied Law of Religious Court in The Field of Marriage, held in IAIN Imam Bonjol, Padang, on June 11, 2005.

Hariyanto, Erie, dan Ni'matunnuriyah Ni'matunnuriyah. "Advokat Syariah Dalam Mediasi Perkara Perceraian Menurut Maqashid Al 
Fajar Sugianto and Slamet Suhartono

Syariah." ULUL ALBAB Jurnal Studi Islam 18, no. 1 (31 Juli 2017): 117. https://doi.org/10.18860/ ua.v18i1.4277.

Hansen, Maren, "The Influence of French Law on Legal Development of Saudi Arabia", Arab Law Quarterly, Volume 2, Part-3, (August, 1987).

Hefni, Wildani, "Genealogi Studi Hukum Islam di Perguruan Tinggi Keagamaan Islam Indonesia": (Genealogy of Islamic Law Study in Indonesian Islamic Religious College), al-Ihkam, Volume 13, No. 1 (June, 2018).

Khoiri, Nispul, "Pemikiran Politik Hukum Islam Muhammadiyah" (Political Thought of Muhammadiyah Islamic Law), Al-Syir'ah, Journal of Sciences of Syari ah and Law, Vol. 47, No. 1 (June, 2013).

Latif, Abdul and Ali, Hasbi, "Politik Hukum" (Politics of Law), Jakarta: Sinar Grafika, 2011.

Maimun and Haq, Ainul, "Melacak Motivasi dan Efektifitas Peraturan Daerah Bernuansa Syariah di Pamekasan" (Tracing Down the Motivation and Effectiveness of Regional Regulation Having the Syariah Nuance in Pamekasan), al-Ihkam, Volume 13, No. 1 (June, 2018).

Manan, Bagir, "Teori dan Politik Konstitusi" (Theory and Constitutional Politics), Law Faculty of Indonesia Islamic University, 2003.

Marzuki, Peter Mshmud, "Penelitian Hukum" (Legal Research), Jakarta: Prenada Media, 2005.

Muttaqien, Dadang, "Peradilan Agama dan Kompilasi Hukum Islam Dalam Tata Hukum Indonesia" (Religious Court and the Islamic Law Compilation in Indonesian Legal Structure), Yogyakarta: UII Press, 1999.

Ni'mah, Zulfatun, "The Violation on Women's Rights in the Unilateral Divorce in Sasak Community from a Feminist Legal Theory", alIhkam, Volume 13, no. 1, (June, 2018).

Rojak, Jeje Abdul, "Menyisipkan Politik Hukum dalam Sosialisasi Norma Islam Kedalam Sistem Hukum Nasional" (Inserting Legal Politics in 
Socialization of Islamic Norms into the National Legal System), alDaulah, Volume 7, No. 2 (October, 2017).

Suryanegara, Ahmad Mansyur, "Menemukan Sejarah: Wacana Pergerakan Islam di Indonesia": (Finding a History: Discourse of Islamic Movement in Indonesia), Bandung: Mizan, 1998.

Thaid, Hasballah, "Tajdid Reaktualisasi dan Elastisitas Hukum Islam" (Tajdid Re-actualization and Elasticity of Islamic Law). This paper is presented at the Seminar of Judges and Court Secretaries of Religious Courts throughout North Sumatra Province, Medan, June 12, 2002.

Zaini, Achmad, "Model Interpretasi al-Qur'an Abdullah Saeed" (Model of Al-Qur'an Interpretation of Abdullah Saeed), Jurnal Islamica, Volume 6, No. 1 (September, 2011). 